\title{
Changes in monoterpene mixing ratios during summer storms in rural New Hampshire (USA)
}

\author{
K. B. Haase ${ }^{1, *}$, C. Jordan ${ }^{1}$, E. Mentis ${ }^{1, * *}$, L. Cottrell ${ }^{1}$, H. R. Mayne ${ }^{2}$, R. Talbot ${ }^{1, * * *}$, and B. C. Sive ${ }^{1, * * * *}$ \\ ${ }^{1}$ University of New Hampshire Institute of Earth, Oceans, and Space, Morse Hall, 8 College Road, Durham NH 03824, USA \\ ${ }^{2}$ University of New Hampshire Department of Chemistry, Parsons Hall, 23 Academic Way, Durham NH 03824, USA \\ * present address: US Geological Survey, National Center, 12201 Sunrise Valley Dr., MS 432, Reston VA 20192, USA \\ ** present address: US Military Academy, Department of Chemistry and Life Science, West Point NY 10996, USA \\ **** present address: Department of Chemistry, Appalachian State University, Boone NC 28608, USA \\ ***** present address: Department of Earth \& Atmospheric Sciences, The University of Houston, Houston TX 77204, USA
}

Received: 19 May 2011 - Published in Atmos. Chem. Phys. Discuss.: 20 July 2011

Revised: 7 October 2011 - Accepted: 25 October 2011 - Published: 17 November 2011

\begin{abstract}
Monoterpenes are an important class of biogenic hydrocarbons that influence ambient air quality and are a principle source of secondary organic aerosol (SOA). Emitted from vegetation, monoterpenes are a product of photosynthesis and act as a response to a variety of environmental factors. Most parameterizations of monoterpene emissions are based on clear weather models that do not take into account episodic conditions that can drastically change production and release rates into the atmosphere. Here, the monoterpene dataset from the rural Thompson Farm measurement site in Durham, New Hampshire is examined in the context of a set of known severe storm events. While some storm systems had a negligible influence on ambient monoterpene mixing ratios, the average storm event increased mixing ratios by $0.59 \pm 0.21 \mathrm{ppbv}$, a factor of $93 \%$ above pre-storm levels. In some events, mixing ratios reached the 10's of ppbv range and persisted overnight. These mixing ratios correspond to increases in the monoterpene emission rate, ranging from 120 to $1240 \mathrm{~g} \mathrm{~km}^{-2} \mathrm{~h}^{-1}$ compared to an estimated clear weather rate of 116 to $193 \mathrm{~g} \mathrm{~km}^{-2} \mathrm{~h}^{-1}$. Considering the regularity of storm events over most forested areas, this could be an important factor to consider when modeling global monoterpene emissions and their resulting influence on the formation of organic aerosols.
\end{abstract}

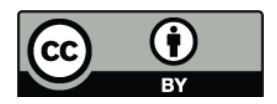

Correspondence to: K. B. Haase (khaase@usgs.gov)

\section{Introduction}

Monoterpenes and other volatile organic compounds (VOCs) are released by vegetation in response to various sources of stress, including heat, light, drought, physical trauma and infestation (Kesselmeier and Staudt, 1999; Räisänen et al., 2008; Niinemets, 2010; Holopainen and Gershenzon, 2010). They can also be released from ground litter that has fallen from trees (Räisänen et al., 2008). The global budget for monoterpene emissions is estimated to be $127 \mathrm{Tg} \mathrm{C}$ per year, comprising an important part of the biogenic VOC budget (Guenther et al., 1995). Monoterpenes react readily with atmospheric oxidants (i.e. $\mathrm{OH}, \mathrm{O}_{3}, \mathrm{NO}_{3}, \mathrm{Cl}$ ) to form an array of products including oxygenated VOCs. These compounds can go on to nucleate into secondary organic aerosol (SOA) or adsorb onto preexisting nuclei (Martínez et al., 1998, 1999; Griffin et al., 1999; Lee et al., 2006a, b; Cai and Griffin, 2006; Ng et al., 2007). The particles formed from organic compounds, such as monoterpenes, are thought to play an important role in controlling the radiative balance of the atmosphere (Goto et al., 2008; Heald et al., 2008). Thus, considerable effort is underway to quantify global monoterpene fluxes to understand the interactions between ecosystems, climate and air quality (Kroll and Seinfeld, 2008). To date, most studies have focused on quantifying fluxes from typical, healthy ecosystems, although there is increasing interest in understanding how ecosystems respond to parasitic pressures, as this could be a feedback mechanism important to predicting future climate conditions (Karl et al., 2008; $\mathrm{Ar}$ neth and Niinemets, 2010).

There are very few data available on how precipitation and intense storm events alter monoterpene emissions, although the limited number of observations to date have indicated that storms may largely induce monoterpene emissions (Schade

Published by Copernicus Publications on behalf of the European Geosciences Union. 
et al., 1999; Bouvier-Brown et al., 2009; Bamberger et al., 2011). Monoterpene fluxes from a ponderosa pine forest have been noted to be $\sim 130 \%$ greater than predicted as a result of precipitation events (Holzinger et al., 2006). Summertime storm systems can bring intense winds and hail, which can knock branches, leaves, and needles from trees, thereby acting as a form of mechanical stress known to increase monoterpene emissions (Schade and Goldstein, 2003; Räisänen et al., 2008). The rainfall associated with storm systems soaks the leaves and needles, which can increase monoterpene emissions in certain plant and tree species (Janson, 1992). Therefore, the goal of this work is to examine the influence of storm systems on ambient monoterpene levels in a rural forested area.

\section{Experimental}

\subsection{Measurements at Thompson Farm}

Since 2004, atmospheric VOC measurements have been made using a Proton Transfer Reaction - Mass Spectrometer (PTR-MS) instrument at the University of New Hampshire (UNH) AIRMAP network monitoring site at Thompson Farm in Durham, New Hampshire $\left(43.1078^{\circ} \mathrm{N}\right.$, $70.99518^{\circ}$ W) (Fig. 1). From 2004 to May 2009, measurements were made in open agricultural fields where alfalfa and corn were grown (White et al., 2009). From June 2009 onward, measurements were made in a new facility approximately $1 \mathrm{~km}$ from the old measurement site. The new measurement site is surrounded by a mixed forest that is predominantly composed of White Pine (Pinus strobus) and Red Oak (Quercus ruba). The forest development is nearing late stage, as it has been in regrowth since the 1900s, when the region was clear-cut for agricultural uses (Perron et al., 2004).

The PTR-MS instrument samples a continuous stream of ambient air without any preconcentration stage. The sample stream is mixed with $\mathrm{H}_{3} \mathrm{O}^{+}$reagent ions in a drift tube reaction chamber. The $\mathrm{H}_{3} \mathrm{O}^{+}$reacts with compounds in the sample stream that have a proton affinity greater than water $\left(>692 \mathrm{~kJ} \mathrm{~mol}^{-1}\right)$ to form protonated ions with limited fragmentation. The resulting positive ions are detected using a mass spectrometer to determine the mixing ratio of the target compounds. An in depth discussion of the PTRMS technique can be found in several recent review articles (Lindinger et al., 1998; Hayward et al., 2002; de Gouw and Warneke, 2006; Blake et al., 2009), and the operational details of the PTR-MS at Thompson Farm have been described previously (Ambrose et al., 2007, 2010; White et al., 2008; Jordan et al., 2009; Talbot et al., 2011). All operational parameters have remained essentially the same, except for moving the instrument to the new building in June 2009. The PTR-MS was operated with an ion source water flow rate of $11 \mathrm{~cm}^{3} \mathrm{~min}^{-1}$, a discharge current of $8 \mathrm{~mA}$ and a $600 \mathrm{~V}$ potential, giving a primary ion signal of $2-10 \times 10^{6} \mathrm{~Hz}$. The

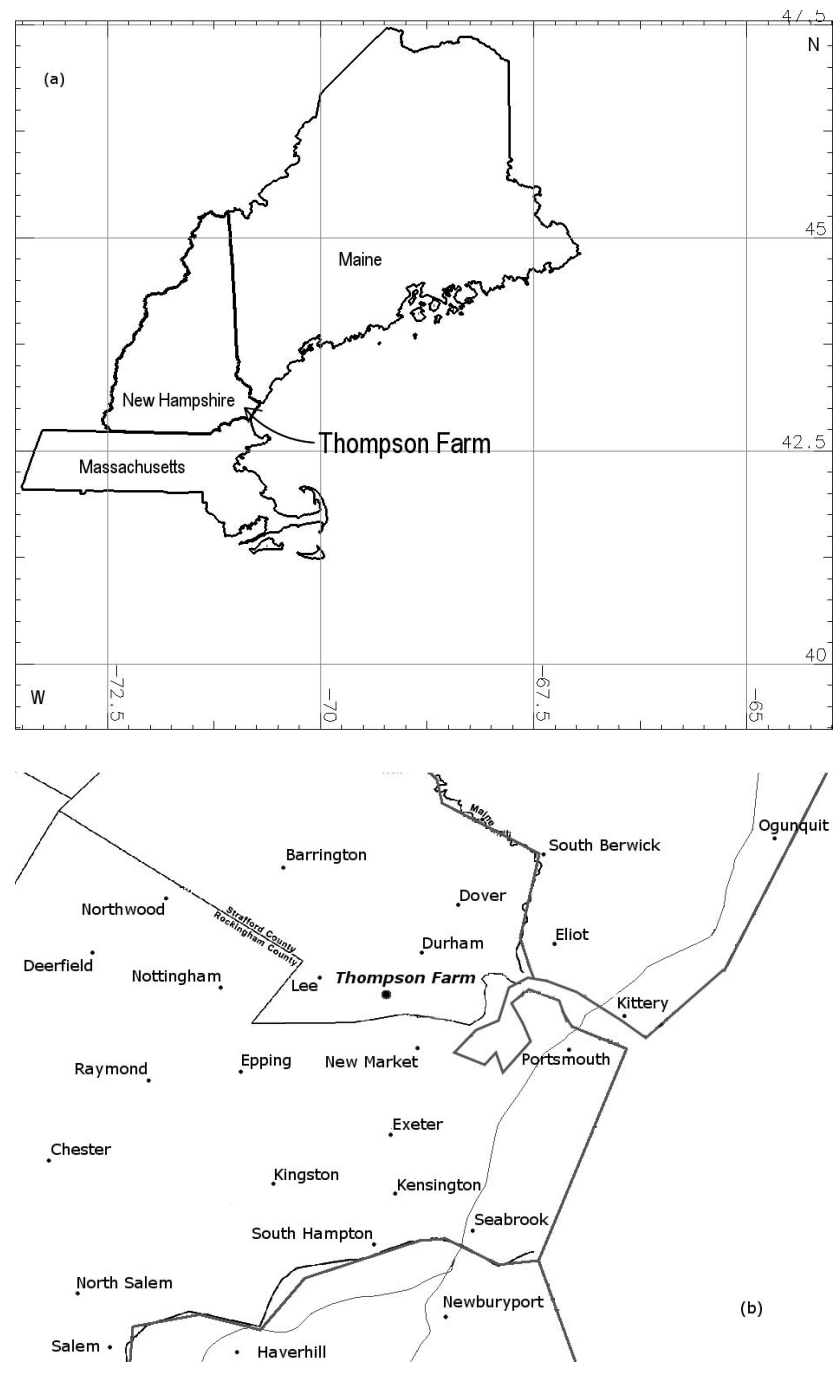

Fig. 1. (a) The location of Thompson Farm with respect to the New England region, (b) Expanded view of the measurement site.

ion source extraction voltages were tuned to keep the contaminant $\mathrm{O}_{2}^{+}$signal less than $1 \%$ of the primary ion signal $\left(\mathrm{H}_{3} \mathrm{O}^{+}\right)$, ensuring that the primary ionization pathway was through the proton transfer reaction with $\mathrm{H}_{3} \mathrm{O}^{+}$. The drift tube was kept at $2.0 \mathrm{mbar}, 600 \mathrm{~V}$, and $45^{\circ} \mathrm{C}$, corresponding to reduced field strength of $132 \mathrm{Td}\left(\mathrm{Td}=1 \times 10^{-17} \mathrm{~V} \mathrm{~cm}^{2}\right)$. The PTR-MS quadrupole mass spectrometer was operated in single ion mode, monitoring a mass table of 47 discrete $\mathrm{m} / \mathrm{z}$ channels with a dwell time of 10-20 s per channel, yielding a measurement cycle of $7.25 \mathrm{~min}$. The signal at $\mathrm{m} / \mathrm{z} 137 \mathrm{was}$ used to monitor the total mixing ratio of monoterpene compounds, as it is not possible to speciate isobaric monoterpenes using the PTR-MS technique. The major monoterpene fragment ion $(\mathrm{m} / \mathrm{z}, 81)$ was also monitored as a measure of the relative fragmentation of the compounds sampled. Rigorous parameterization of the PTR-MS under the drift tube and ion source conditions used in this study has shown 
that the measurements of monoterpenes do not need correction for ambient humidity. The limit of detection (LOD) for monoterpenes was $0.050 \mathrm{ppbv}(2 \sigma)$ and the measurement precision was $11 \%(2 \sigma)$. Since late 2008 , background measurements were obtained for one hour after each $24 \mathrm{~h}$ of measurements. During PTR-MS background signal determination, the instrument made measurements while drawing ambient air through a $1.27 \mathrm{~cm}\left(0.5^{\prime \prime}\right)$ outer diameter, $46 \mathrm{~cm}\left(18^{\prime \prime}\right)$ long $0.5 \%$ Pd-on-alumina bead catalytic converter held at $625^{\circ} \mathrm{C}$. A secondary standard containing camphene was automatically introduced into the stream for $30 \mathrm{~min}$ after background signal determination, thereby comprising our online calibration system. The flow of the secondary standard cycles through three different flow rates over time, so that for every three background/calibration periods, a three point calibration curve was generated. This $25.5 \mathrm{~h}$ cycle ensures that the frequency of calibrations did not introduce a temporal bias into the PTR-MS data stream. This online calibration system provided metric of instrument response on a daily basis, and was done in conjunction with more thorough offline calibrations done using a primary standard and a standard dilution system (Apel Riemer Environmental). The standard contained a mixture of $\alpha$-pinene, limonene, camphene, and 3 -carene. These compounds were selected because they are the dominant monoterpenes observed at the Thompson Farm site (White et al., 2008), making the calibration representative of the suite of compounds normally measured by the instrument.

Additional measurements were obtained from the AIRMAP database for Thompson Farm. These include ozone (Thermo 49C-PS, precision of $\pm 1.0 \mathrm{ppbv}$ ), photolysis rate $\left(j \mathrm{NO}_{2}\right)$ (Metcon Model $\left.2, \pm 1.5 \times 10^{-6} \mathrm{~s}^{-1}\right)$, particle number density (TSI 3022A, $\pm 10 \%$ ), wind speed (Gill Sonic, $\pm 2 \%$ ), atmospheric pressure (All Weather 7120, $\pm 0.88 \mathrm{mbar}$ ), temperature (All Weather 6190D, $\pm 0.3 \%$ ) and relative humidity (All Weather $6190 \mathrm{D}, \pm 1.5 \%) .{ }^{1}$ For 2004 to 2007, all measurements from the original Thompson Farm site were used. For 2008, the PTR-MS was still at the original site, but $j \mathrm{NO}_{2}$ was obtained from the new site. All other measurements were obtained from the original site. For 2009, all measurements were performed at the new field site. All other chemical and meteorological data were averaged over a $5 \mathrm{~min}$ time period that is on the approximate time scale as the PTR-MS dataset. Further details about these measurements and the AIRMAP network can be found at http://www.airmap.sr.unh.edu/ (Mao and Talbot, 2004; Talbot et al., 2011).

\subsubsection{Determination of storm events}

Because of the highly localized scope of intense storm events (such as thunder and hail storms) and the lack of a specific

\footnotetext{
${ }^{1}$ The use of company names is for identification purposes only, and does not constitute endorsement by the US Geological Survey.
}

instrument at Thompson Farm to determine rain and hail at high time resolution, proxy sources were used to establish time periods when intense summer storms were active over the field site. Deducing the presence of storm events at Thompson Farm was a two stage process. The United States National Climatic Data Center (NOAA NCDC) maintains a publicly accessible storm event database (http://www4. ncdc.noaa.gov/cgi-win/wwcgi.dll?wwEvent $\sim$ Storms). This database is regional in scale and contains data on events from eyewitness sources. It is organized by city and county, but these data do not provide explicit listings of hail and storm events over Thompson Farm because it is an unmanned station in a sparsely populated area. Storm history data was retrieved for Strafford and Rockingham counties. Events marked as "Hail", "Thunderstorm Wind", "Tornado", and "Funnel Cloud" were chosen as indicators of periods in time when storms would be active over Thompson Farm. These types of events were selected as they typically occur during the summer growing season, when vegetative transpiration processes are most active and monoterpene production is greatest (Fig. 2a, b). The dates of the events were then used to select precipitation data determined by weather radar.

The hourly precipitation rates were obtained from the National Climatic Data Center (NCDC) NEXRAD Doppler radar inventory for the day of each event and $24 \mathrm{~h}$ thereafter (http://www.ncdc.noaa.gov/nexradinv/). For this study, data from the radar site located in Boston, MA was used (callsign: $\mathrm{KBOX}$ ). These data are available at 5-10 min time resolution and are calculated for $1 \mathrm{~km}^{2}$ grid squares. The precipitation data are binned into rates of $2.54 \mathrm{~mm} \mathrm{~h}^{-1}$ to $6.35 \mathrm{~mm} \mathrm{~h}^{-1}$, and $6.35 \mathrm{~mm} \mathrm{~h}^{-1}$ bins thereafter (WMO, 2008). The radar data were manually analyzed to determine the onset of light precipitation $\left(0.00 \leq 2.54 \mathrm{~mm} \mathrm{~h}^{-1}\right)$, surges in precipitation rate $\left(>2.54 \mathrm{~mm} \mathrm{~h}^{-1}\right)$, duration of the surge, and cessation of precipitation. On days in which there were multiple peaks in precipitation, each peak was considered a unique event. Peak precipitation periods were defined as the point in time when rainfall increased to over $2.54 \mathrm{~mm} \mathrm{~h}^{-1}$ in the $1 \mathrm{~km}^{2}$ Thompson Farm grid square or over $6.35 \mathrm{~mm} \mathrm{~h}^{-1}$ in the three adjacent grid squares. The three square filter allows this condition to be met in the cases in which storms pass over the site, but precipitation in the Thompson Farm grid square does not increase as rapidly as in the surrounding areas. A summary of the storm events determined by radar analysis is listed in Table 1 .

\subsection{Classification of storm event types}

Overall, 34 storm events were identified, of which 33 were examined in detail. One storm caused a power failure that prevented complete data collection, and is not included in Table 1. Among the storm events used in this analysis, most storms were associated with compact, episodic systems that did not bring prolonged periods of precipitation and did not last for more than a few hours at a time. The 
Table 1. Storm events at Thompson Farm, identified by radar data. All times are given in UTC. (Local Time $=$ UTC $-4 \mathrm{~h}$ ). Type is the classification assigned, as described in the text (Sect. 2.3).

\begin{tabular}{|c|c|c|c|c|c|c|c|c|c|c|}
\hline Type & $\begin{array}{l}\text { Start Precip. }{ }^{a} \\
\text { (UTC) }\end{array}$ & $\begin{array}{l}\text { Peak Precip. }{ }^{b} \\
\text { (UTC) }\end{array}$ & $\begin{array}{l}\text { End Peak }{ }^{\mathrm{c}} \\
\text { (UTC) }\end{array}$ & $\begin{array}{l}\text { End Precip. } \\
\text { (UTC) }\end{array}$ & $\begin{array}{l}\text { Peak Rate }^{\mathrm{d}} \\
\left(\mathrm{mm} \mathrm{h}^{-1}\right)\end{array}$ & $\begin{array}{l}3 \mathrm{~h} \text { Pre-Event } \mathrm{e} \\
(\mathrm{ppbv} \pm 1 \sigma)\end{array}$ & $\begin{array}{l}\text { Start to Peak } \\
(\mathrm{ppbv} \pm 1 \sigma)\end{array}$ & $\begin{array}{l}\text { Peak Precip. } \\
(\operatorname{ppbv} \pm 1 \sigma)\end{array}$ & $\begin{array}{l}\text { Peak to Stop } \\
(\mathrm{ppbv} \pm 1 \sigma)\end{array}$ & $\begin{array}{l}3 \mathrm{~h} \text { Post-Event } \\
(\mathrm{ppbv} \pm 1 \sigma)\end{array}$ \\
\hline B & $6 / 8 / 0522: 35$ & 6/8/05 23:09 & 6/9/05 00:09 & 6/9/05 04:29 & $12.7-19.05$ & $0.32 \pm 0.09$ & $0.45 \pm 0.11$ & $1.05 \pm 0.23$ & $1.04 \pm 0.41$ & $3.78 \pm 0.56$ \\
\hline A & 7/14/05 20:12 & $7 / 14 / 0520: 29$ & $7 / 14 / 0521: 24$ & $7 / 14 / 0522: 15$ & $6.35-12.7$ & $0.45 \pm 0.19$ & $0.79 \pm 0.18$ & $1.52 \pm 0.53$ & $2.60 \pm 0.33$ & $2.52 \pm 0.32$ \\
\hline B & 7/22/05 23:09 & $7 / 22 / 05 \quad 23: 45$ & $7 / 23 / 0500: 36$ & $7 / 23 / 0500: 45$ & $2.54-6.35$ & $0.88 \pm 0.31$ & $1.36 \pm 0.38$ & $1.51 \pm 0.30$ & $1.69 \pm 0.20$ & $1.82 \pm 0.56$ \\
\hline $\mathrm{C}$ & 7/23/05 01:47 & f & $\mathrm{g}$ & $7 / 23 / 0503: 59$ & $2.54-6.35$ & $1.55 \pm 0.44$ & $1.09 \pm 1.35$ & & & $1.34 \pm 0.44$ \\
\hline B & $7 / 27 / 0521: 31$ & $7 / 27 / 05$ 22:05 & $7 / 27 / 0522: 35$ & $7 / 28 / 0501: 55$ & $2.54-6.35$ & $0.95 \pm 0.21$ & $1.04 \pm 0.38$ & $2.00 \pm 0.41$ & $1.78 \pm 0.55$ & $1.03 \pm 0.19$ \\
\hline B & 5/21/06 22:41 & & & 5/22/06 01:13 & $0-2.54$ & $0.12 \pm 0.04$ & $0.25 \pm 1.17$ & $0.25 \pm 0.00$ & $0.25 \pm 1.17$ & $0.18 \pm 0.04$ \\
\hline B & 8/2/06 21:24 & $8 / 2 / 0621: 33$ & $8 / 2 / 0622: 28$ & 8/2/06 23:43 & $2.54-6.35$ & $0.90 \pm 0.26$ & $1.36 \pm 0.43$ & $0.82 \pm 0.26$ & $1.95 \pm 0.61$ & $1.74 \pm 0.42$ \\
\hline D & 9/24/06 18:49 & & & 9/24/06 20:03 & $0-2.54$ & $0.18 \pm 0.04$ & $0.20 \pm 1.05$ & & & $0.21 \pm 0.03$ \\
\hline B & $5 / 11 / 0712: 35$ & $5 / 11 / 0712: 44$ & $5 / 11 / 0714: 33$ & $5 / 11 / 07 \quad 16: 47$ & $19.05-25.4$ & $0.45 \pm 0.08$ & $0.35 \pm 0.06$ & $0.96 \pm 0.38$ & $0.63 \pm 0.21$ & $0.27 \pm 0.11$ \\
\hline B & $6 / 2 / 0723: 56$ & $6 / 3 / 0700: 32$ & 6/3/07 01:06 & 6/3/07 01:19 & $0-2.54$ & $0.14 \pm 0.05$ & $0.20 \pm 0.10$ & $0.38 \pm 0.15$ & $0.38 \pm 0.13$ & $0.39 \pm 0.17$ \\
\hline $\mathrm{D}$ & $6 / 4 / 07 \quad 16: 58$ & $6 / 4 / 07$ 19:27 & $6 / 4 / 0720: 54$ & $6 / 4 / 0721: 33$ & $6.35-12.7$ & $0.09 \pm 0.02$ & $0.08 \pm 0.02$ & $0.13 \pm 0.03$ & $0.13 \pm 0.02$ & $0.10 \pm 0.03$ \\
\hline $\mathrm{C}$ & 9/9/07 08:19 & & & 9/9/07 09:51 & $2.54-6.35$ & $1.33 \pm 0.26$ & $1.10 \pm 0.96$ & & & $0.76 \pm 0.17$ \\
\hline B & 9/9/07 09:51 & 9/9/07 11:12 & 9/9/07 11:59 & 9/9/07 12:16 & $2.54-6.35$ & $1.27 \pm 0.37$ & $0.76 \pm 0.07$ & $0.94 \pm 0.15$ & $0.73 \pm 0.03$ & $0.44 \pm 0.13$ \\
\hline B & $9 / 9 / 07 \quad 15: 15$ & 9/9/07 15:43 & 9/9/07 16:41 & $9 / 9 / 07$ 17:27 & $2.54-6.35$ & $0.45 \pm 0.14$ & $0.23 \pm 0.03$ & $0.25 \pm 0.05$ & $0.20 \pm 0.04$ & $0.21 \pm 0.05$ \\
\hline B & $6 / 20 / 08$ 18:59 & 6/20/08 19:40 & $6 / 20 / 0820: 50$ & $6 / 20 / 08$ 20:54 & $12.7-19.05$ & $0.10 \pm 0.03$ & $0.15 \pm 0.08$ & $0.19 \pm 0.05$ & $0.19 \pm 0.05$ & $0.30 \pm 0.09$ \\
\hline B & $6 / 22 / 08 \quad 17: 55$ & $6 / 22 / 0818: 57$ & $6 / 22 / 08$ 19:48 & $6 / 22 / 0822: 24$ & $2.54-6.35$ & $0.19 \pm 0.11$ & $0.26 \pm 0.09$ & $0.33 \pm 0.07$ & $0.48 \pm 0.11$ & $0.25 \pm 0.13$ \\
\hline B & $6 / 23 / 08 \quad 17: 59$ & $6 / 23 / 08 \quad 20: 25$ & $6 / 23 / 0822: 26$ & $6 / 23 / 0822: 54$ & $12.7-19.05$ & $0.16 \pm 0.05$ & $0.58 \pm 0.22$ & $0.35 \pm 0.18$ & $0.15 \pm 0.04$ & $0.22 \pm 0.14$ \\
\hline $\mathrm{D}$ & $6 / 24 / 0820: 16$ & & & $6 / 24 / 0822: 00$ & $0-2.54$ & $0.23 \pm 0.11$ & $0.34 \pm 0.91$ & $0.34 \pm 0.00$ & $0.34 \pm 0.91$ & $0.51 \pm 0.09$ \\
\hline B & $\mathrm{h}$ & $6 / 27 / 08$ 19:06 & $6 / 27 / 08$ 19:48 & $\mathrm{h}$ & 0.00 & $0.29 \pm 0.13$ & $0.47 \pm 0.00$ & $0.37 \pm 0.14$ & $0.37 \pm 0.14$ & $0.22 \pm 0.13$ \\
\hline B & $6 / 29 / 0821: 39$ & $6 / 29 / 0821: 52$ & 6/29/08 $23: 24$ & 6/30/08 00:38 & $2.54-6.35$ & $0.16 \pm 0.06$ & $0.23 \pm 0.10$ & $0.21 \pm 0.05$ & $0.26 \pm 0.07$ & $0.32 \pm 0.06$ \\
\hline B & 6/30/08 07:34 & & & 6/30/08 09:00 & $0-2.54$ & $0.43 \pm 0.13$ & $0.71 \pm 0.91$ & & & $0.78 \pm 0.28$ \\
\hline $\mathrm{C}$ & 7/3/08 22:07 & & & & $0-2.54$ & $0.48 \pm 0.13$ & $0.57 \pm 0.91$ & & & $0.50 \pm 0.08$ \\
\hline B & 7/18/08 00:00 & 7/18/08 22:30 & 7/18/08 23:54 & 7/19/08 00:04 & $19.05-25.4$ & $0.43 \pm 0.39$ & $1.98 \pm 1.64$ & $2.32 \pm 1.04$ & $2.60 \pm 0.15$ & $1.73 \pm 0.91$ \\
\hline $\mathrm{C}$ & $7 / 19 / 0800: 41$ & 7/19/08 01:17 & $7 / 19 / 0802: 08$ & $7 / 19 / 0802: 55$ & $2.54-6.35$ & $1.92 \pm 1.07$ & $2.05 \pm 0.80$ & $1.30 \pm 0.42$ & $1.53 \pm 1.44$ & $1.48 \pm 0.27$ \\
\hline $\mathrm{C}$ & 7/19/08 06:09 & 7/19/08 06:47 & 7/19/08 07:19 & 7/19/08 07:49 & $2.54-6.35$ & $1.45 \pm 0.29$ & $0.62 \pm 0.13$ & $0.51 \pm 0.14$ & $0.93 \pm 0.17$ & $0.98 \pm 0.23$ \\
\hline $\mathrm{C}$ & 7/24/08 12:07 & $7 / 24 / 08 \quad 13: 33$ & $7 / 24 / 08 \quad 15: 19$ & $7 / 24 / 08 \quad 15: 43$ & $25.4-31.75$ & $1.71 \pm 0.33$ & $0.73 \pm 0.17$ & $0.70 \pm 0.11$ & $0.66 \pm 0.06$ & $0.44 \pm 0.08$ \\
\hline $\mathrm{D}$ & $7 / 24 / 0816: 43$ & 7/24/08 17:00 & $7 / 24 / 0818: 51$ & & $12.7-19.05$ & $0.62 \pm 0.15$ & $0.51 \pm 0.11$ & $0.42 \pm 0.07$ & $0.58 \pm 0.91$ & $0.53 \pm 0.00$ \\
\hline B & 7/31/08 20:39 & 7/31/08 21:46 & 8/1/08 00:17 & 8/1/08 00:45 & $19.05-25.4$ & $0.29 \pm 0.07$ & $0.29 \pm 0.05$ & $1.12 \pm 0.40$ & $2.14 \pm 0.83$ & $1.58 \pm 0.62$ \\
\hline \multicolumn{11}{|c|}{ The PTR-MS was relocated at this point } \\
\hline D & 6/26/09 09:19 & & & $6 / 26 / 09$ 10:44 & $0-2.54$ & $6.14 \pm 0.37$ & $4.94 \pm 0.39$ & & & $3.59 \pm 0.51$ \\
\hline A & $8 / 11 / 0911: 33$ & 8/11/09 12:16 & 8/11/09 13:29 & 8/11/09 13:59 & $12.7-19.05$ & $4.50 \pm 1.20$ & $3.83 \pm 0.64$ & $4.62 \pm 1.62$ & $2.48 \pm 0.56$ & $1.18 \pm 0.66$ \\
\hline A & $8 / 11 / 0921: 50$ & & & 8/12/09 00:00 & $2.54-6.35$ & $0.34 \pm 0.12$ & $0.87 \pm 0.25$ & & & $0.87 \pm 0.28$ \\
\hline A & 8/21/09 23:41 & $8 / 21 / 09$ 23:47 & $8 / 22 / 0900: 51$ & $8 / 22 / 0901: 59$ & $12.7-19.05$ & $0.91 \pm 0.25$ & $0.45 \pm 0.06$ & $6.75 \pm 2.64$ & $6.55 \pm 2.15$ & $6.72 \pm 2.20$ \\
\hline A & 8/22/09 17:00 & 8/22/09 17:08 & 8/22/09 18:21 & 8/22/09 21:11 & $19.05-25.4$ & $0.80 \pm 0.41$ & $0.52 \pm 0.15$ & $2.95 \pm 1.33$ & $3.01 \pm 1.82$ & $0.79 \pm 0.19$ \\
\hline
\end{tabular}

${ }^{\text {a }}$ Start Precip. is the time at which the radar first detected rain.

${ }^{b}$ Peak Precip. is when the rate of precipitation increased over $2.54 \mathrm{~mm} \mathrm{~h}^{-1}$.

${ }^{c}$ End Peak is when the peak dropped below $2.54 \mathrm{~mm} \mathrm{~h}^{-1}$. End precip. is the last radar measurement that showed precipitation.

${ }^{\mathrm{d}}$ Peak Rate is the maximum range of precipitation (in $\mathrm{mm} \mathrm{h}^{-1}$ ) measured.

e $3 \mathrm{~h}$ Pre-Event, Start to Peak, Peak Precip, Peak to Stop, and $3 \mathrm{~h}$ Post-Peak are the average and standard deviation of the monoterpene mixing ratios at each stage of an event

${ }^{\mathrm{f}}$ Blank values in the peak precipitation columns indicate that the threshold to determine peak rate was never exceeded.

g Blank values in the End Precip. column indicate that extended precipitation followed the onset of rain, and the average after the initial mixing ratio response was used instead.

${ }^{\mathrm{h}}$ No rainfall detected over $\mathrm{TF}$, but intense precipitation was measured during peak in adjacent grid squares.

number of storm events varied on a year-to-year basis. In 2004 (least active year, and the storm with the power failure), there was just one day where storm events occurred, while in 2008 (the most active year), there were 14 days with storm events. The majority of event days fall between June and August, with just 6 days occurring in September or May. On days when there are storm events, it is common for several intense periods of precipitation to occur over Thompson Farm, interspersed with periods of little or no precipitation $\left(<2.54 \mathrm{~mm} \mathrm{~h}^{-1}\right)$. At points in time when the radar predicted precipitation, there were corresponding changes in pressure, humidity, wind speed, and temperature, indicating that the radar gave viable information about the arrival of storm systems to Thompson Farm. This type of analysis is important because not all the storms perturbed the measured monoterpene mixing ratios.

Each event was analyzed in the context of the monoterpene mixing ratio before and after the storm, as well as the diurnal trends in mixing ratio that normally occur at Thompson Farm (Fig. 2b, c). Storms tended to arrive at Thompson Farm around 00:00 UTC (20:00 LT), which also coincided with the formation of a stable nocturnal inversion layer (Talbot et al., 2005). The inversion layer prevents surface emissions from mixing into the free troposphere, so monoterpene mixing ratios frequently build up to several parts per billion over night and rapidly drop at sunrise (Fig. 2c). By examining each individual storm event, it was possible to separate the events into different types based on the changes in mixing ratio as the storm passed over Thompson Farm. This analysis revealed four types of storm events. Examples of each event type are shown in Figs. 3-7, along with $j \mathrm{NO}_{2}$ (to show daylight), ozone, particles (to show air quality changes over the course of the event), pressure, humidity, temperature, and wind speed. They are shown in a constant $48 \mathrm{~h}$ window in order to indicate the relative time of day.

The Type A storm events showed a rapid increase in monoterpene mixing ratios that coincided with the passage of a storm. These increases ranged from a few hundred pptv to tens of ppbv and then remained elevated for several hours. The Type A events were relatively uncommon, with only five 

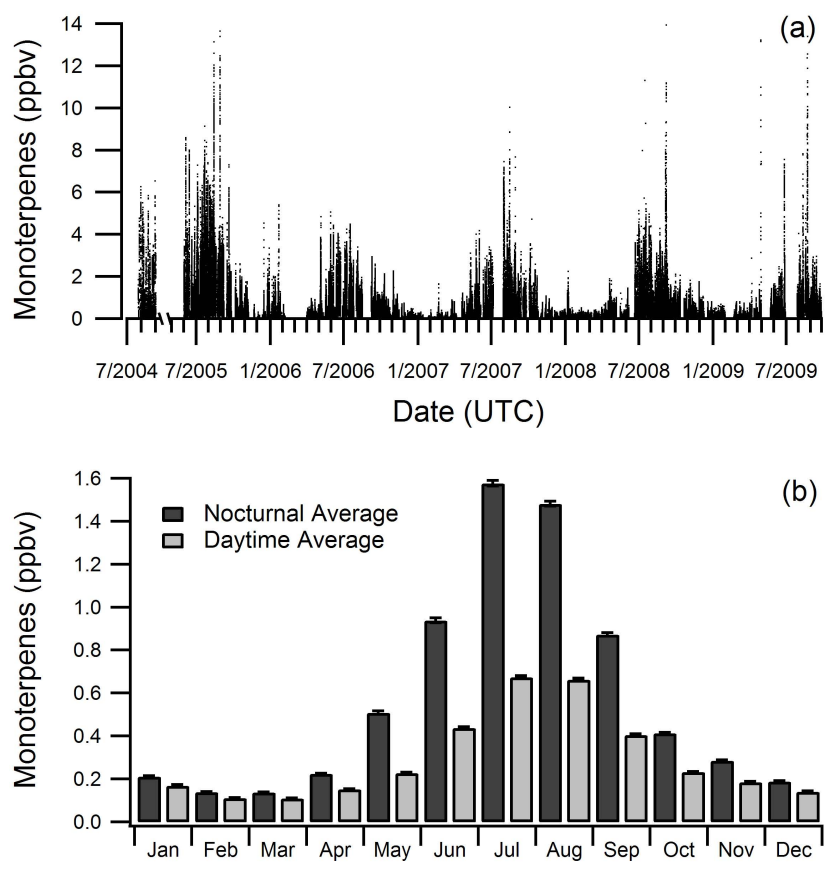

Month

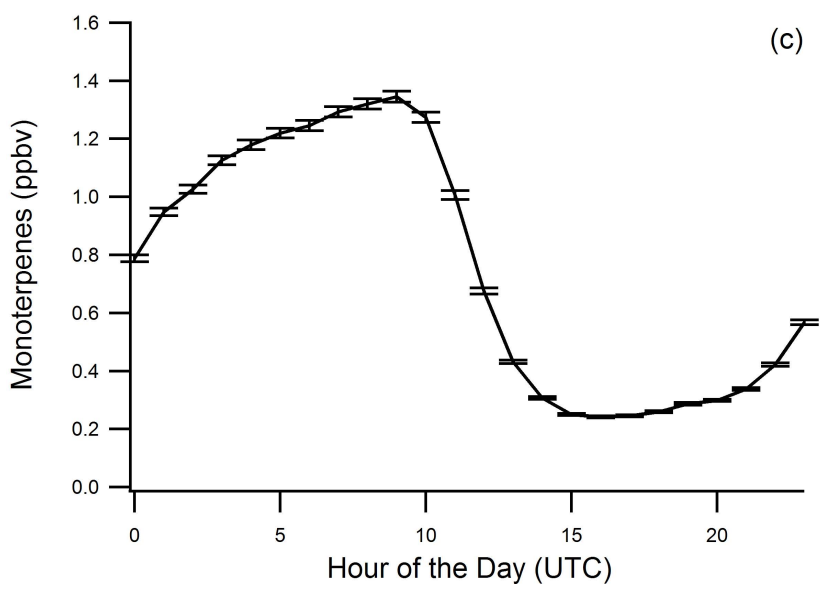

Fig. 2. (a) The data set of monoterpenes collected by PTR-MS at Thompson Farm from 2004 to 2009, showing daily, seasonal, and inter-annual variability. (b) The monthly average daytime and nocturnal average mixing ratio of monoterpenes, showing that monoterpene mixing ratios are elevated at night during the summer months. (c) The average mixing ratio of monoterpenes as a function of the time of day from May through September, showing mixing ratios increasing throughout the night and decreasing at daybreak.

present in this study. An example of a Type A event is displayed in Fig. 3.

Type B storm events were marked by increases in monoterpene mixing ratios that peaked during, or soon after a storm's passage (Fig. 4). The mixing ratio of monoterpenes then either returned to a level similar to their initial values, or increased due to the formation of a nocturnal boundary layer. Compared to Type A events, these events were not tempo-

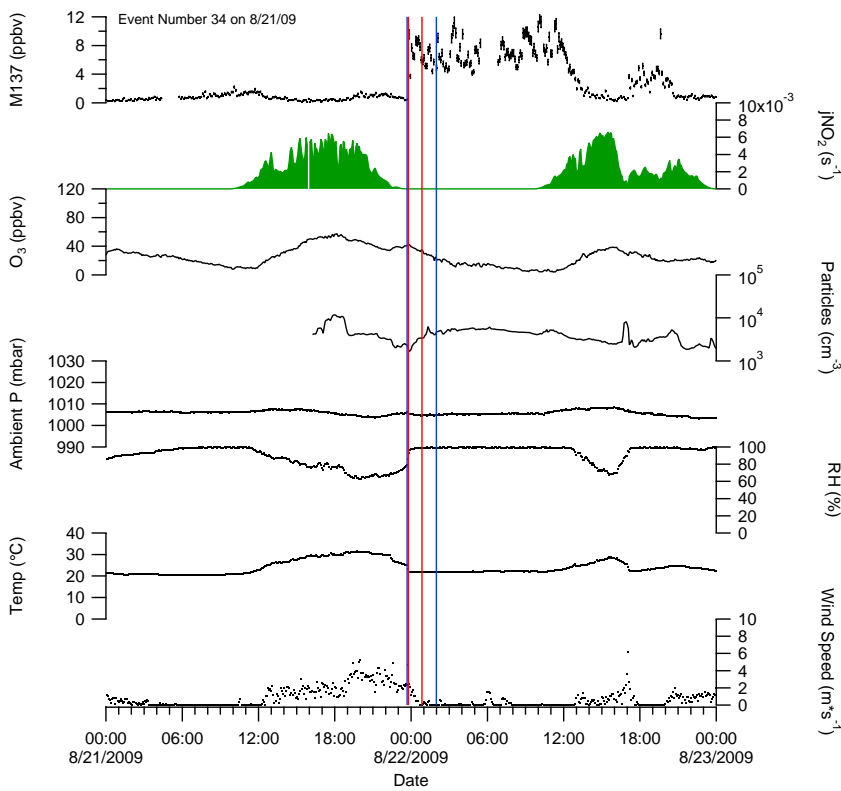

Fig. 3. An example of a Type A event, from 22 August 2009 (UTC), showing a large increase in monoterpenes (M137) at the same time as a rain storm arrives at Thompson farm. Ozone $\left(\mathrm{O}_{3}\right)$, particles, atmospheric pressure (Ambient $\mathrm{P}$ ), relative humidity $(\mathrm{RH})$, temperature (Temp), and wind speed during the storm event are also shown. Blue lines indicate the period of precipitation as determined by the radar, while red lines indicate peak precipitation as described in the text. The arrival precipitation is validated by simultaneous changes in meteorological conditions.

rally restricted and occurred during both daytime and nighttime hours and the measured monoterpene mixing ratios during the events were generally smaller.

Type $\mathrm{C}$ events were characterized by an overall decrease in monoterpene mixing ratios. These events sometimes had a small, short lived increase in monoterpenes, but then mixing ratios dropped to below pre-storm levels, as illustrated in Fig. 5. These events typically coincided with high wind speeds, and thus may simply be the effect of strong mixing and dilution with free tropospheric air from aloft. During the study period, 6 Type $\mathrm{C}$ events were observed.

Type D events were distinct because they did not appear to have an observable effect on the ambient mixing ratio of monoterpenes. A total of 5 events did not show a change in monoterpene mixing ratios. An example of a Type D event is shown in Fig. 6.

The type assignments for each storm event identified by radar are shown in the "Type" column of Table 1. Out of the original 33 events identified, 28 were considered to have perturbed monoterpene mixing ratios in connection with the storms passage (Type A, B, or C), while 5 did not (Type D); one event caused a power outage for which there were no monoterpene measurements. The precipitation effecting Thompson Farm occurred over a total of 26 days. 


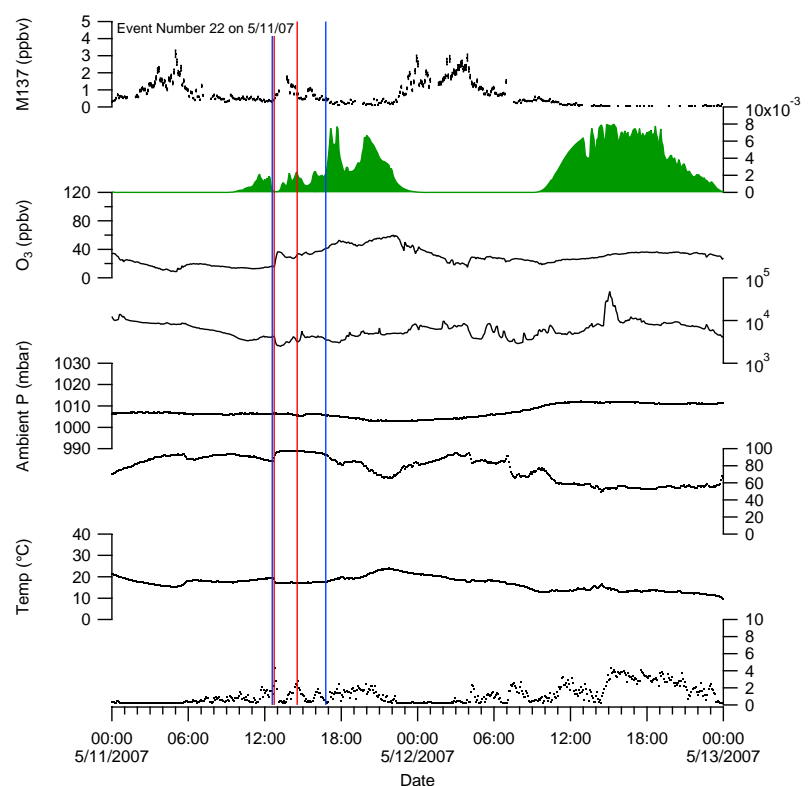

Fig. 4. An example Type B event, in which the mixing ratios of monoterpenes peak for a brief period of time, from 11 May 2007.

The change in monoterpene mixing ratio as each storm passed over the site was determined from the difference between the average mixing ratio $3 \mathrm{~h}$ before each event and the maximum during the period of precipitation. Figure 7 shows the average, median, minimum and maximum change in monoterpene mixing ratios for each event type where monoterpene levels were perturbed by the storm.

In order to quantify the trends in monoterpene mixing ratios as storms pass over Thompson Farm, the mixing ratios were grouped into bins: (i) $3 \mathrm{~h}$ before the onset of rainfall, (ii) immediately before, during, and after peak precipitation, and (iii) $3 \mathrm{~h}$ after cessation of precipitation. The $3 \mathrm{~h}$ windows were selected to capture the general conditions before and after the event, while attempting to exclude other factors controlling monoterpene emissions. The measurements in each bin were averaged for each event, and each event type grouping (A, B, C, and D). For periods in which there was no discernable peak in rainfall, the average mixing ratio for the entire precipitation event was averaged. The change in mixing ratios over the course of the storm for each type of event are shown in Fig. 8a, along with the average wind speeds and temperatures (Fig. 8b, c).

\section{Analysis of storm events}

Across all of the events, monoterpene mixing ratios increased by an average of $0.59 \pm 0.21 \mathrm{ppbv}$ ( $93 \%$ above initial values) during the passage of storms. Type A events had an average increase of $2.68 \pm 1.12 \mathrm{ppbv}(429 \%)$, the Type B events had a smaller increase of $0.55 \pm 0.16 \mathrm{ppbv}(125 \%)$

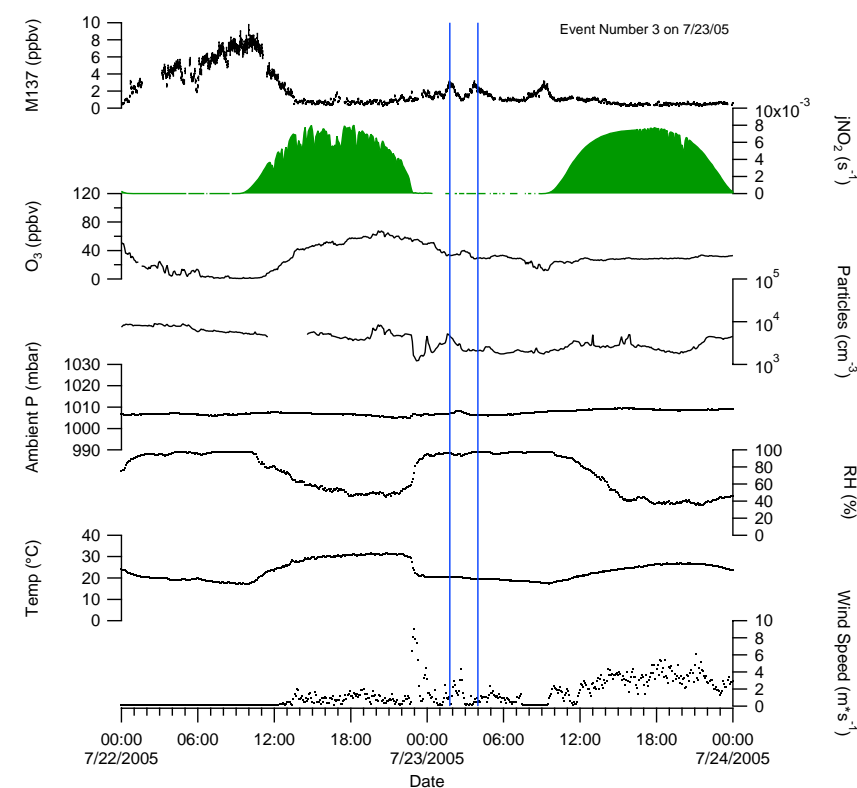

Fig. 5. An example of a Type $C$ event, in which the storm passage coincides with a decrease in monoterpene mixing ratios from 23 July 2005 . In this example, no increase in precipitation rate beyond $2.54 \mathrm{~mm} \mathrm{~h}^{-1}$ was detected.

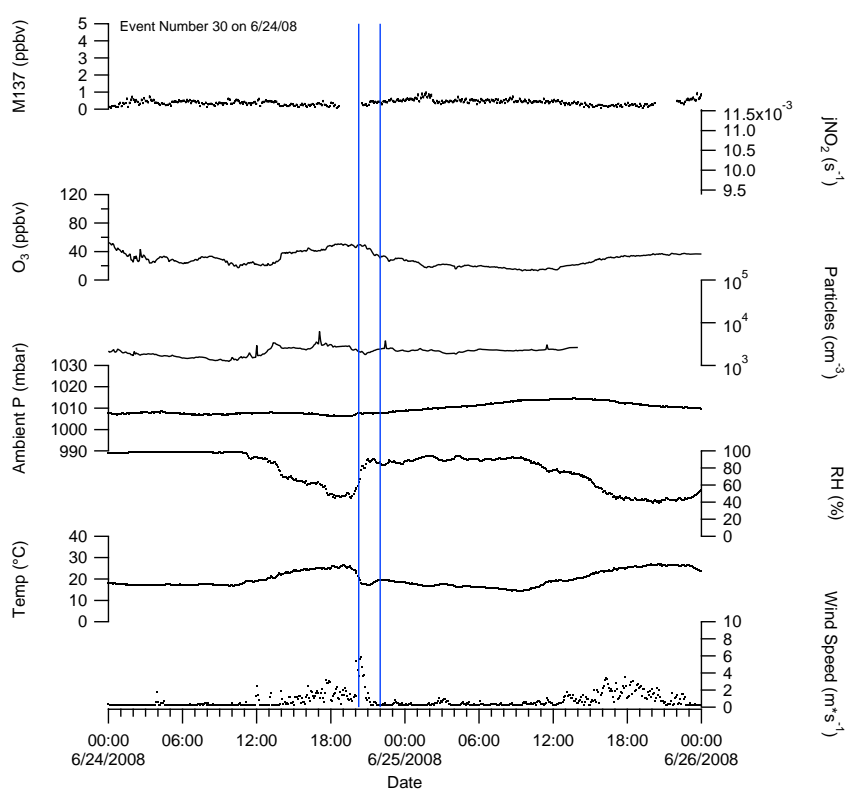

Fig. 6. An example of a Type D event, in which the storm passage had little influence on mixing ratios, from 24 June 2008. $j \mathrm{NO}_{2}$ was not measured during this event because the instrument was not operational.

and Type $\mathrm{C}$ events decreased by $0.33 \pm 0.13$ ppbv ( $-23 \%)$. Type D events showed average increase of $0.03 \pm 0.01 \mathrm{ppbv}$ $(12 \%)$ which is similar of the precision of the measurements and therefore is not significant. 


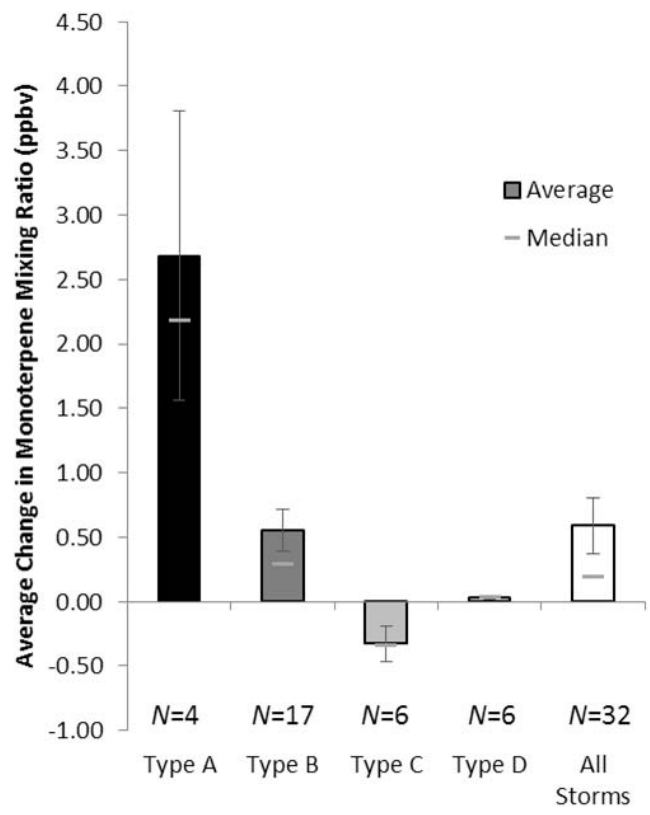

Fig. 7. The median (horizontal lines) and average (bars) change in monoterpene mixing ratios for each type of storm event. Across all events (white bars), there is an average increase of $0.59 \pm 0.21 \mathrm{ppbv}$. Amongst the groups identified in the text, Type A (black bars) had increases of $2.68 \pm 1.12 \mathrm{ppbv}$, Type B events (dark grey) had increases of $0.55 \pm 0.16 \mathrm{ppbv}$, Type $\mathrm{C}$ events (grey) decreased by $0.33 \pm 0.13$ ppbv. Type D events (light grey) did not show a measurable change.

The ratios of the PTR-MS signals at $m / z 137$ and $m / z 81$ observed during the storm events were not different that than those observed during non-storm periods. This could indicate that the mixture of monoterpene compounds present during events was similar to those normally emitted, or that the composite fragmentation of the mixture during the storm event was not measurably different. The consistent ratio of $\mathrm{m} / \mathrm{z} 137$ to $\mathrm{m} / \mathrm{z} 81$ would be explained if the monoterpenes emitted as a result of the soaking of leafs and needles stimulating emission of compounds (Schade et al., 1999), or if the compounds are released as a result of damage to needles and branches that rupture storage structures that would otherwise release monoterpenes at a lower rate (Fuentes et al., 2000).

During Type A events, the mixing ratios of monoterpenes increased rapidly during the peak rate of precipitation ( $>2.54 \mathrm{~mm} \mathrm{~h}^{-1}$; Fig. 8a). After the storm passed, the mixing ratios remained elevated at an average of $2.10 \pm 1.31 \mathrm{ppbv}$ above pre-storm levels. For these events, the arrival of storms was very sudden, and there was often just a single measurement between the start of precipitation and the onset of the peak precipitation rate. The Type A event on 11 August 2009 was excluded from the bin-averaging analysis because it occurred in the middle of the night, when the nocturnal inversion layer was present and monoterpene mixing ratios were already elevated. Four out of the five Type A events occurred after the PTR-MS had been relocated at new Thompson Farm observatory. It is very likely that this phenomenon is the result of the different surroundings at the new measurement site.

Type B events showed much more subtle changes in monoterpene mixing ratios during storm passages. The average mixing ratio was elevated above background at all stages (Fig. 8a), increasing to a maximum of $0.41 \pm 0.16 \mathrm{ppbv}$ above pre-storm levels after peak precipitation. On average, the post-storm mixing ratio was elevated by $0.40 \pm 0.21 \mathrm{ppbv}$ over initial conditions. The post-storm signal was quite variable for Type B events, as subsequent arrival of new storms, sustained winds, or nighttime accumulation of monoterpenes affected the average mixing ratio of the last $3 \mathrm{~h}$ bin. Generally, this final value appears to be biased upwards by nighttime increases in monoterpenes.

Type $\mathrm{C}$ events revealed a mixing ratio pattern that reflected the temporary decrease scenario outlined above. The mixing ratio of monoterpenes decreased to a minimum of $0.62 \pm 0.13$ ppbv (Fig. 8a). After the storm, the average levels remained lower than initial values, at $0.57 \pm 0.13 \mathrm{ppbv}$. Compared to the other events, the initial mixing ratios were quite high, $1.41 \pm 0.38 \mathrm{ppbv}$ versus $0.28 \pm 0.14$ (for Type D) to $0.62 \pm 0.14 \mathrm{ppbv}$ (for Type A events). This was not the effect of a single point bias either, as 5 out of 6 events started between 1 and 2 ppbv. Type $C$ events also were not associated with compact, short term storms, but were related to large regional events that lasted for many hours to days. It has been noted elsewhere that long rain events do not seem to coincide with the same burst in monoterpene emissions that short events do, and this could be the case here as well (Holzinger et al., 2006). The increased background monoterpene levels observed in Type $C$ events may be the result of reduced transport and photochemical activity that results from cloudy, cool, and calm conditions.

Type D events did not display a significant change in monoterpene mixing ratios associated with the passage of storms.

\subsection{Environmental conditions associated with storm events}

In order to understand the environmental factors driving the different types of monoterpene storm events identified, the local meteorological conditions surrounding the event were examined. Meteorological conditions impose significant controls on ambient monoterpene mixing ratios. Emission rates are a function of temperature and can be increased resulting from mechanical stress on leaves. High winds can cause leaves and needles to be torn from branches, branches to break and fall from trees, and produce greater flexing than trees normally experience during clear weather conditions. Additionally, heavy rainfall and hail also can cause leaves and needles to become detached, as well as causing damage from impact to leaves that remain attached. These types of stress would cause emissions of monoterpenes to increase. 

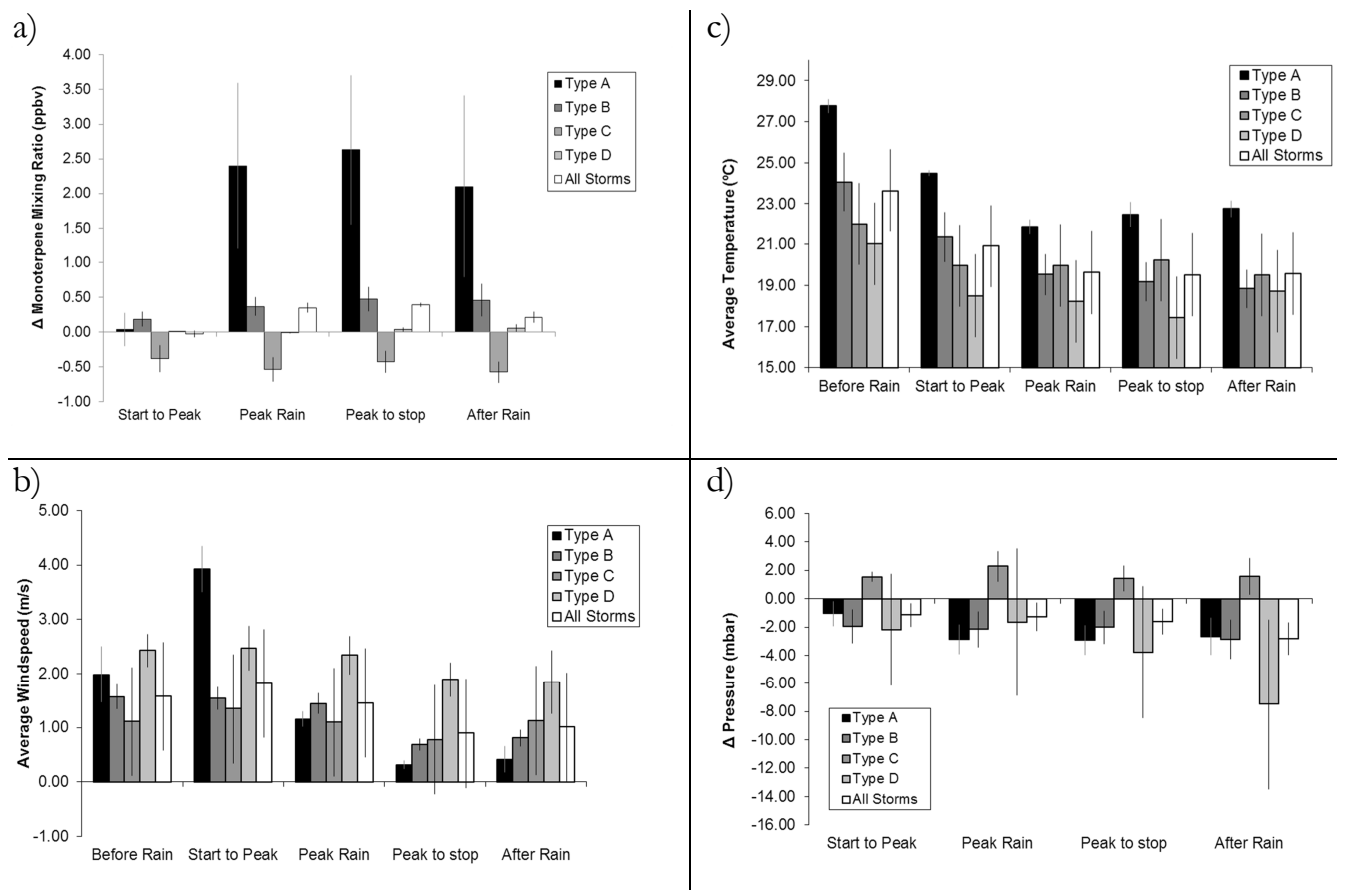

Fig. 8. The averages during each phase of the different types of storms. (a) The change in mixing ratio of monoterpenes, (b) wind speed, (c) temperatures, (d) change in atmospheric pressure as storm systems pass over Thompson Farm

High wind speeds also are indicative of greater advection, removing ground level monoterpenes and transporting them aloft, resulting in measured levels to be lower than those made under similar but calm conditions. Therefore, these meteorological factors were examined for each event type in order to better understand their influence on the measured monoterpene mixing ratios.

There were only sparse meteorological data available for Type A events; the associated instruments were not functioning during two events that occurred on 11 August 2009. The data presented are for the remaining three Type A events; these events are characterized by higher wind speeds than the other event types until the arrival of the peak precipitation. The doubling of the average wind speed from $1.99 \pm 0.52 \mathrm{~m} \mathrm{~s}^{-1}$ to $3.92 \pm 0.42 \mathrm{~m} \mathrm{~s}^{-1}$ at the start of precipitation is notable. Additionally, there was a large average decrease in atmospheric pressure that coincided with the peak rate of precipitation that was not present in the other events. After the passage of the storm, Type A events had the calmest wind conditions $\left(0.41 \pm 0.24 \mathrm{~m} \mathrm{~s}^{-1}\right)$. These events also had the highest average temperatures, $27.8 \pm 0.33^{\circ} \mathrm{C}$ before the onset of rainfall and the highest average precipitation rate $\left(10.67 \mathrm{~mm} \mathrm{~h}^{-1}\right)$. These factors combined indicate that Type A events were characterized by a period of high emission activity before the storm (resulting from the high temperatures), high mechanical stress from wind and precipitation, followed by calm conditions when monoterpenes accumulated under the stable nocturnal inversion layer.
Type $\mathrm{B}$ events had slower average wind speeds before $\left(1.44 \pm 0.20 \mathrm{~m} \mathrm{~s}^{-1}\right)$ and during peak rainfall $\left(1.36 \pm 0.20 \mathrm{~m} \mathrm{~s}^{-1}\right)$ and then subsided to an average of $0.78 \pm 0.10 \mathrm{~m} \mathrm{~s}^{-1}$ after passage of the storm. Temperatures were cooler than in Type A events, starting at $23.8 \pm 1.2^{\circ} \mathrm{C}$ before the storm, and the ambient pressure drop was smaller. The average maximum precipitation rate also was lower, $7.13 \mathrm{~mm} \mathrm{~h}^{-1}$. In comparison to Type A events, Type B events exhibited lower stresses and emission activity, and greater mixing, indicating that measured monoterpene mixing ratios were smaller than those observed during the Type A events. Worth noting is that several individual Type B events had the potential to be Type A events: both high temperatures and precipitation rates were present, but persistent winds after the passage of the storm likely caused the monoterpenes emitted to be transported away from the measurement site.

Type $\mathrm{C}$ events exhibited very low, consistent wind speeds throughout each storms passage, varying from 0.78 to $1.35 \mathrm{~m} \mathrm{~s}^{-1}$. The average temperature before the storm was $22.0 \pm 1.5^{\circ} \mathrm{C}$, lower than Type A and B events. Type C events experienced an average maximum precipitation rate of $5.93 \mathrm{~mm} \mathrm{~h}^{-1}$, less than Type B and almost half that of Type A events. In contrast to other event types, the ambient pressure rose over the course of Type $\mathrm{C}$ events, possibly indicating the departure of a frontal system. Type $\mathrm{C}$ events were quite different from the other event types because of their consistent temperatures, low wind speeds, and moderate monoterpene 
mixing ratios ( $\sim 1 \mathrm{ppbv})$. Compared to Type $\mathrm{A}$ and Type $\mathrm{B}$ events, Type $\mathrm{C}$ events did not have strong stress factors triggering enhanced monoterpene emissions, but rather the low wind speeds limited the ventilation rate, resulting in elevated mixing ratios during the course of the event.

Type D events featured consistently high average wind speeds, starting at $2.43 \pm 0.30 \mathrm{~m} \mathrm{~s}^{-1}$ before the storm and ending at $1.84 \pm 0.59 \mathrm{~m} \mathrm{~s}^{-1}$. Type $\mathrm{D}$ events also had the lowest temperatures, initially averaging $21.0 \pm 3.0^{\circ} \mathrm{C}$ before rain and dropping to $18.7 \pm 2.6^{\circ} \mathrm{C}$ after the event. The average ambient pressure showed a large decrease after the rain stopped, in contrast to the other events which showed stable pressures after the period of peak precipitation, possibly signifying a relationship to stronger systems that could produce sustained strong winds. Additionally, the average maximum precipitation rate for storms in this event type was the lowest, at $3.81 \mathrm{~mm} \mathrm{~h}^{-1}$. These values indicate that Type D events occurred when there were low emission rates and low mechanical stress, but high rates of advection, which would limit variation in monoterpene mixing ratios.

In a broader scope, this analysis shows that the large, enduring monoterpene events (Type A) occurred when a combination of environmental and stress factors (leaf soaking, wind stress, and high temperature) stimulated intense monoterpene emissions, while low wind speeds and minimal transport allowed for these elevated mixing ratios to persist for long time periods. In contrast, monoterpene levels were not able to build up at Thompson Farm during Type D events because monoterpene production was low, and high winds kept the atmosphere well mixed, preventing monoterpene accumulation. High temperatures that stimulate monoterpene production were not present, and high winds increased mixing of ground level air to the atmosphere. Type $\mathrm{B}$ and $\mathrm{C}$ events exist somewhere between Type A and D, where different combinations of emission factors and mixing lead to short increases in monoterpene mixing ratios with air mass mixing and dilution processes ultimately removing them from the area.

\subsection{Estimation of storm-induced monoterpene emissions}

The total mass of monoterpenes released into the atmosphere during storms was estimated based on the observed increases in monoterpene mixing ratios. The Type A events showed the strongest emissions coupled with minimal transport, mixing, and dilution (Sect. 4.1), and were used to form a rough estimate of storm induced emissions. For example, the event that occurred at 23:41 UTC on 21 August 2009, a sudden and intense hail storm passed over Thompson Farm. During the storm, the monoterpene levels increased to an average of $6.56 \mathrm{ppbv}$, which persisted until day break. The wind speed dropped to $0.1 \mathrm{~m} \mathrm{~s}^{-1}$ after the start of the peak precipitation rate and remained calm throughout the night, indicative of a stable nocturnal inversion layer (Shepson et al., 1991; Mao and Talbot, 2004; Talbot et al., 2005; White et al., 2008).
If the majority of the monoterpenes emitted as a result of the storm were captured in the boundary layer, the mass of monoterpenes is given by the following expression:

$$
\Delta M=\Delta C \cdot V
$$

where $\Delta M$ is increase in the total mass of monoterpenes aloft, $\Delta C$ is the increase in monoterpene concentration $\left(\mathrm{g} \mathrm{m}^{-3}\right)$, and $V$ is the volume of the air between the canopy and the top of the boundary layer. Unfortunately, it is not possible to ascertain the mixing depth of the boundary layer during these events. It is also not certain whether the emissions originate from the trees or from branches and litter on the ground. In order to put a lower limit on emissions, the volume was calculated from the height of the sample inlet above the forest canopy at the new Thompson Farm site $(5 \mathrm{~m})$. During this event, the concentration of monoterpenes changed from $5.4 \times 10^{-6} \mathrm{~g} \mathrm{~m}^{-3}$ to $3.6 \times 10^{-5} \mathrm{~g} \mathrm{~m}^{-3}$, resulting in an increase of $3.1 \times 10^{-5} \mathrm{~g} \mathrm{~m}^{-3}$. As this increase in monoterpenes was on the same timescale as the PTR-MS measurements $(\sim 7.5 \mathrm{~min})$ the start of the storm for the monoterpene mixing ratios to reach these values, the subsequent emission rate was $1240 \mathrm{~g} \mathrm{~km}^{-2} \mathrm{~h}^{-1}$, or $6.24 \times 10^{10} \mathrm{molec} \mathrm{m}^{-2} \mathrm{~s}^{-1}$. The results of this analysis for the other Type A events are listed in Table 2.

Direct measurements of vertical wind speeds and night time boundary layer heights would help constrain these otherwise rudimentary estimates. The degree of influence also could vary in different areas over which a storm has passed, as precipitation rates, wind speed, and forest composition change along its path. This is exemplified by the estimation for 11 August 2009, in which only the edge of the storm passed over Thompson Farm. Also of note, this method of estimation does not account for monoterpenes advected aloft during windy periods of the storm, and so this could lead to under-estimation of emissions at the measurement site.

The emission estimates presented here are quite large compared to estimates made for calm conditions, i.e. when storms were not present. Generally nocturnal monoterpene mixing ratios increased at an average rate of $0.27( \pm 0.24)$ ppbv per hour on nights where winds were calm $\left(<1 \mathrm{~m} \mathrm{~s}^{-1}\right)$ and ozone levels were low $(<10 \mathrm{ppbv})$. It is not possible to ascertain the boundary layer height on any given night; however, if the boundary layer typically is between 75 and $125 \mathrm{~m}$ (Talbot et al., 2005), then these calm weather mixing ratio increases correspond to average nocturnal fluxes in the range of 116 to $193 \mathrm{~g} \mathrm{~km}^{-2} \mathrm{~h}^{-1}$. The estimates of storm-induced emissions presented here are also on the order of, and usually much larger than the estimated emissions of MEGAN 2.02 (Model of Emissions of Gases and Aerosols from Nature) and BEIS 3.0 (Biogenic Emissions Inventory System) during July in New England (150-300 $\mathrm{g} \mathrm{km}^{-2} \mathrm{~h}^{-1}$ ) (Sakulyanontvittaya et al., 2008). In comparison to these estimates, the values obtained from Type A storm events range from $120-1240 \mathrm{~g} \mathrm{~km}^{-2} \mathrm{~h}^{-1}$. 
Table 2. Summary of estimated storm-induced monoterpene emissions at Thompson Farm. Mass MT per area is the grams of monoterpenes per square meter of ground area, and the corresponding emission rate of monoterpenes are in $\left(\right.$ molec $\left.\mathrm{m}^{-2} \mathrm{~s}^{-1}\right)$ and $\left(\mathrm{g} \mathrm{km}^{-2} \mathrm{~h}^{-1}\right)$.

\begin{tabular}{lccc}
\hline Date (UTC) & $\begin{array}{c}\text { Mass MT per Area } \\
\left(\mathrm{g} \mathrm{m}^{-2}\right)\end{array}$ & $\begin{array}{c}\text { Emission Rate } \\
\left(\mathrm{molec} \mathrm{m}^{-2} \mathrm{~s}^{-1}\right)\end{array}$ & $\begin{array}{c}\text { Emission Rate } \\
\left(\mathrm{g} \mathrm{km}^{-2} \mathrm{~h}^{-1}\right)\end{array}$ \\
\hline $8 / 11 / 200921: 50$ & $1.5 \times 10^{-5}$ & $6.0 \times 10^{9}$ & 119 \\
$8 / 21 / 200923: 49$ & $1.5 \times 10^{-4}$ & $6.2 \times 10^{10}$ & 1240 \\
$8 / 22 / 200917: 00$ & $6.1 \times 10^{-5}$ & $2.5 \times 10^{10}$ & 490 \\
\hline
\end{tabular}

The monoterpenes released into the atmosphere by storm events furnish substantial amounts of reactive organic carbon to the atmosphere that could be participating in the formation of new aerosol particles or condensing onto preexisting nuclei. The PTR-MS measurements do not provide any information about the relative amounts of speciated monoterpenes released during storm events, so it is not possible to estimate secondary organic aerosol (SOA) yield based on levels of individual monoterpenes. The mass yield of SOA from monoterpene oxidation falls between $0.5 \%$ and $58 \%$ (Lee et al., 2006b), so these events could substantially increase the change the amount and composition of SOA present near the surface under certain conditions. Storm-induced monoterpenes could thus be a periodic contributor to the missing SOA budget (Volkamer et al., 2006). However, because rainout is simultaneously removing particles from the atmosphere at the same time reactive monoterpenes are being released, it is not possible to directly quantify new aerosol formation (if any) as a result of these events using the available particle number density data. Furthermore, without size and composition data, it cannot be determined if the aerosol levels observed after the storm contain any SOA resulting from enhanced monoterpene emissions and oxidation. Additional data on aerosol properties during storm events might elucidate whether enhanced monoterpenes mixing ratios result in formation of SOA and, if so, whether new particle formation occurs or monoterpene oxidation results in the growth of pre-existing particles.

\section{Conclusions}

Thirty three storm events between May 2004 and October 2009 were isolated using the NWS database of severe storm events and NEXRAD radar data. These events were evaluated and categorized on the basis of temporal variation of monoterpene mixing ratios. The storm events were classified as Type A (increase in monoterpene mixing ratio coupled with a long residence time), Type B (increase in mixing ratio, but short residence time), Type $\mathrm{C}$ (small decrease in mixing ratio with passage of storm), and Type $\mathrm{D}$ (no apparent change). The observed changes in monoterpene mixing ratio are related to ambient temperatures, which control emission rates, and wind speed, which transport monoterpenes aloft. Large increases (Type A events) occurred under warm, calm conditions, while no change was observed under cold, windy storm conditions.

Comparing various meteorological factors, four out of five Type A events were observed at the new Thompson Farm site and three of those coincided with the formation of a stable nocturnal boundary layer. In contrast to Type A events, Type B events typically did not show the formation of a stable boundary layer, and thus the monoterpene mixing ratios quickly dropped following the storm due to mixing and dilution. It is also possible that some or all of the Type B events were the same as Type A events, with the distinction originating from slight differences in meteorological conditions. Type $\mathrm{C}$ events generally coincided with the passage of intense precipitation and wind bursts during an otherwise long, steady rain event. Type D events featured high winds that resulted in well mixed air masses at the measurement site. Overall, monoterpene mixing ratios increased by $93 \%$ on average when a storm passed through the area, with much larger increases for Type A and Type B events. Based on the ambient monoterpene levels observed during Type A events at the new Thompson Farm site it is estimated that these severe storm events could yield monoterpene emission rates in the range of $119-1240 \mathrm{~g} \mathrm{~km}^{-2} \mathrm{~h}^{-1}$.

Given that most events (Type B) coincide with high winds that may cause compounds to be advected into the free troposphere, storm systems could be serving as an important transport mechanism for injecting monoterpenes into the upper atmosphere, where they could then oxidize and form SOA or condense on preexisting particles. Injection of additional monoterpenes into the surface layer of the free troposphere as a result of storms may help explain enhanced levels of secondary organic aerosol observed in other studies (Heald et al., 2005). This aspect is particularly important as the frequency and intensity of severe thunderstorms is predicted to increase over time in response to climate change, with an additional two strong event days per year by the end of the century (Trapp et al., 2007, 2009).

Performing additional flux measurements in areas frequently subject to storms should help elucidate the processes driving the monoterpene emissions during the events. It would be particularly useful to have fast response speciated monoterpene data in order to better predict potential SOA yields. Measurements of aerosol size and composition would also elucidate the amount of aerosol actually formed as a direct result of the storm-derived monoterpene emissions. Airborne measurement of biogenic VOCs around the base of storms also may yield information about the amounts of monoterpenes and SOA advected aloft as a result of monoterpene emissions. By increasing our understanding of this topic, it should be possible to determine whether storminduced monoterpenes could be an important pathway for aerosol formation in the troposphere. 
Acknowledgements. Financial Support for this work was provided through the Office of Oceanic and Atmospheric Research at the National Oceanic and Atmospheric Administration under grants NA04OAR4600154 and NA05OAR4601080. We thank E. Fitz, T. Hagan, K. Garrison, K. Carpenter, Y. Zhou, R. Russo, J. Ambrose, M. White, H. Mao and others who have contributed to the measurements and management of the extensive AIRMAP database. The US Geological Survey also provided time and resources for the completion of the final manuscript. We would like to thank our reviewers for their thoughtful input.

Edited by: J. Williams

\section{References}

Ambrose, J. L., Mao, H., Mayne, H. R., Stutz, J., Talbot, R., and Sive, B. C.: Nighttime nitrate radical chemistry at Appledore Island, Maine during the 2004 International Consortium for Atmospheric Research on Transport and Transformation, J. Geophys. Res., 112, D21302, doi:10.1029/2007jd008756, 2007.

Ambrose, J. L., Haase, K., Russo, R. S., Zhou, Y., White, M. L., Frinak, E. K., Jordan, C., Mayne, H. R., Talbot, R., and Sive, B. C.: A comparison of GC-FID and PTR-MS toluene measurements in ambient air under conditions of enhanced monoterpene loading, Atmos. Meas. Tech., 3, 959-980, doi:10.5194/amt-3959-2010, 2010.

Arneth, A. and Niinemets, Ü.: Induced BVOCs: how to bug our models?, Trends Plant Sci., 15, 118-125, 2010.

Bamberger, I., Hörtnagl, L., Ruuskanen, T. M., Schnitzhofer, R., Müller, M., Graus, M., Karl, T., Wohlfahrt, G., and Hansel, A.: Deposition fluxes of terpenes over grassland, J. Geophys. Res., 116, D14305, doi:10.1029/2010jd015457, 2011.

Blake, R. S., Monks, P. S., and Ellis, A. M.: Proton Transfer Reaction Mass Spectrometry, Chem. Rev., 109, 861-896, doi:10.1021/cr800364q, 2009.

Bouvier-Brown, N. C., Goldstein, A. H., Gilman, J. B., Kuster, W. C., and de Gouw, J. A.: In-situ ambient quantification of monoterpenes, sesquiterpenes, and related oxygenated compounds during BEARPEX 2007: implications for gas- and particle-phase chemistry, Atmos. Chem. Phys., 9, 5505-5518, doi:10.5194/acp-9-5505-2009, 2009.

Cai, X. and Griffin, R. J.: Secondary aerosol formation from the oxidation of biogenic hydrocarbons by chlorine atoms, J. Geophys. Res., 111, D14206, doi:10.1029/2005jd006857, 2006.

de Gouw, J. and Warneke, C.: Measurements of Volatile Organic Compounds in the Earth's Atmosphere Using Proton-TransferReaction Mass Spectrometry, Mass Spectrom. Rev., 26, 223 257, doi:10.1002/mas.20119, 2006.

Fuentes, J. D., Gu, L., Lerdau, M., Atkinson, R., Baldocchi, D., Bottenheim, J. W., Ciccioli, P., Lamb, B., Geron, C., Guenther, A., Sharkey, T. D., and Stockwell, W.: Biogenic Hydrocarbons in the Atmospheric Boundary Layer: A Review, B. Am. Meteorol. Soc., 81, 1537-1575, doi:10.1175/15200477(2000)081; 1537:BHITAB $; 2.3 . C O ; 2,2000$.

Goto, D., Takemura, T., and Nakajima, T.: Importance of global aerosol modeling including secondary organic aerosol formed from monoterpene, J. Geophys. Res., 113, D07205, doi:10.1029/2007jd009019, 2008.
Griffin, R. J., Cocker III, D. R., Flagan, R. C., and Seinfeld, J. H.: Organic aerosol formation from the oxidation of biogenic hydrocarbons, J. Geophys. Res., 104, 3555-3567, doi:10.1029/1998jd100049, 1999.

Guenther, A., Hewitt, C. N., Erickson, D., Fall, R., Geron, C., Graedel, T., Harley, P., Klinger, L., Lerdau, M., McKay, W. A., Pierce, T., Scholes, B., Steinbrecher, R., Tallamraju, R., Taylor, J., and Zimmerman, P.: A global model of natural volatile organic compound emissions, J. Geophys. Res., 100, 8873-8892, doi:10.1029/94jd02950, 1995.

Hayward, S., Hewitt, C. N., Sartin, J. H., and Owen, S. M.: Performance Characteristics and Applications of a Proton Transfer Reaction-Mass Spectrometer for Measuring Volatile Organic Compounds in Ambient Air, Environ. Sci. Technol., 36, 15541560, doi:10.1021/es0102181, 2002.

Heald, C. L., Jacob, D. J., Park, R. J., Russell, L. M., Huebert, B. J., Seinfeld, J. H., Liao, H., and Weber, R. J.: A large organic aerosol source in the free troposphere missing from current models, Geophys. Res. Lett., 32, L18809, doi:10.1029/2005g1023831, 2005.

Heald, C. L., Henze, D. K., Horowitz, L. W., Feddema, J., Lamarque, J. F., Guenther, A., Hess, P. G., Vitt, F., Seinfeld, J. H., Goldstein, A. H., and Fung, I.: Predicted change in global secondary organic aerosol concentrations in response to future climate, emissions, and land use change, J. Geophys. Res., 113, D05211, doi:10.1029/2007jd009092, 2008.

Holopainen, J. K. and Gershenzon, J.: Multiple stress factors and the emission of plant VOCs, Trends Plant Sci., 15, 176-184, 2010.

Holzinger, R., Lee, A., McKay, M., and Goldstein, A. H.: Seasonal variability of monoterpene emission factors for a ponderosa pine plantation in California, Atmos. Chem. Phys., 6, 1267-1274, doi:10.5194/acp-6-1267-2006, 2006.

Janson, R.: Monoterpene concentrations in and above a forest of scots pine, J. Atmos. Chem., 14, 385-394, 1992.

Jordan, C., Fitz, E., Hagan, T., Sive, B., Frinak, E., Haase, K., Cottrell, L., Buckley, S., and Talbot, R.: Long-term study of VOCs measured with PTR-MS at a rural site in New Hampshire with urban influences, Atmos. Chem. Phys., 9, 4677-4697, doi:10.5194/acp-9-4677-2009, 2009.

Karl, T., Guenther, A., Turnipseed, A., Patton, E. G., and Jardine, K.: Chemical sensing of plant stress at the ecosystem scale, J. Geophys Res. and Biogeosciences, 5, 1287-1294, doi:10.5194/bg-5-1287-2008, 2008.

Kesselmeier, J. and Staudt, M.: Biogenic Volatile Organic Compounds (VOC): An Overview on Emission, Physiology and Ecology, J. Atmos. Chem., 33, 23-88, 1999.

Kroll, J. H. and Seinfeld, J. H.: Chemistry of secondary organic aerosol: Formation and evolution of low-volatility organics in the atmosphere, Atmos. Environ., 42, 3593-3624, 2008.

Lee, A., Goldstein, A. H., Keywood, M. D., Gao, S., Varutbangkul, V., Bahreini, R., Ng, N. L., Flagan, R. C., and Seinfeld, J. H.: Gas-phase products and secondary aerosol yields from the ozonolysis of ten different terpenes, J. Geophys. Res., 111, D07302, doi:10.1029/2005jd006437, 2006a.

Lee, A., Goldstein, A. H., Kroll, J. H., Ng, N. L., Varutbangkul, V., Flagan, R. C., and Seinfeld, J. H.: Gas-phase products and secondary aerosol yields from the photooxidation of 16 different terpenes, J. Geophys. Res., 111, D17305, 
doi:10.1029/2006jd007050, 2006b.

Lindinger, W., Hansel, A., and Jordan, A.: On-line monitoring of volatile organic compounds at pptv levels by means of protontransfer-reaction mass spectrometry (PTR-MS) medical applications, food control and environmental research, Int. J. Mass Spectrom., 173, 191-241, 1998.

Mao, H. and Talbot, R.: $\mathrm{O}_{3}$ and $\mathrm{CO}$ in New England: Temporal variations and relationships, J. Geophys. Res., 109, D21304, doi:10.1029/2004jd004913, 2004.

Martínez, E., Cabañas, B., Aranda, A., and Martín, P.: Kinetics of the Reactions of $\mathrm{NO}_{3}$ Radical with Selected Monoterpenes: A Temperature Dependence Study, Environ. Sci. Technol., 32, 3730-3734, doi:10.1021/es970899t, 1998.

Martínez, E., Cabañas, B., Aranda, A., Martín, P., and Salgado, S.: Absolute Rate Coefficients for the Gas-Phase Reactions of $\mathrm{NO}_{3}$ Radical with a Series of Monoterpenes at $\mathrm{T}=298$ to $433 \mathrm{~K}$, J. Atmos. Chem., 33, 265-282, 1999.

Ng, N. L., Chhabra, P. S., Chan, A. W. H., Surratt, J. D., Kroll, J. H., Kwan, A. J., McCabe, D. C., Wennberg, P. O., Sorooshian, A., Murphy, S. M., Dalleska, N. F., Flagan, R. C., and Seinfeld, J. H.: Effect of $\mathrm{NO}_{\mathrm{x}}$ level on secondary organic aerosol (SOA) formation from the photooxidation of terpenes, Atmos. Chem. Phys., 7, 5159-5174, doi:10.5194/acp-7-5159-2007, 2007.

Niinemets, Ü.: Mild versus severe stress and BVOCs: thresholds, priming and consequences, Trends Plant Sci., 15, 145-153, 2010.

Perron, C., J., Bennett, K., and Lee, T. D.: Forest Stewardship Plan for Thompson Farm, Univeristy of New Hampshire, Report, 95, 2004.

Räisänen, T., Ryyppö, A., and Kellomäki, S.: Impact of timber felling on the ambient monoterpene concentration of a Scots pine (Pinus sylvestris L.) forest, Atmos. Environ., 42, 6759-6766, 2008.

Sakulyanontvittaya, T., Duhl, T., Wiedinmyer, C., Helmig, D., Matsunaga, S., Potosnak, M., Milford, J., and Guenther, A.: Monoterpene and Sesquiterpene Emission Estimates for the United States, Environ. Sci. Technol., 42, 1623-1629, doi:10.1021/es702274e, 2008.

Schade, G. W. and Goldstein, A. H.: Increase of monoterpene emissions from a pine plantation as a result of mechanical disturbances, Geophys. Res. Lett., 30, 1380, doi:10.1029/2002g1016138, 2003.

Schade, G. W., Goldstein, A. H., and Lamanna, M. S.: Are monoterpene emissions influenced by humidity?, Geophys. Res. Lett., 26, 2187-2190, doi:10.1029/1999g1900444, 1999.
Shepson, P. B., Hastie, D. R., Schiff, H. I., Polizzi, M., Bottenheim, J. W., Anlauf, K., Mackay, G. I., and Karecki, D. R.: Atmospheric concentrations and temporal variations of $\mathrm{C} 1-$ C3 carbonyl compounds at two rural sites in central Ontario, Atmos. Environ. A-Gen., 25, 2001-2015, doi:10.1016/09601686(91)90280-k, 1991.

Talbot, R., Mao, H., and Sive, B.: Diurnal characteristics of surface level $\mathrm{O}_{3}$ and other important trace gases in New England, $\mathrm{J}$ Geophys. Res., 110, D09307, doi:10.1029/2004jd005449, 2005.

Talbot, R., Mao, H., Feddersen, D., Smith, M., Kim, S. Y., Sive, B., Haase, K., Ambrose, J., Zhou, Y., and Russo, R.: Comparison of Particulate Mercury Measured with Manual and Automated Methods, Atmosphere, 2, 1-20, 2011.

Trapp, R. J., Diffenbaugh, N. S., Brooks, H. E., Baldwin, M. E., Robinson, E. D., and Pal, J. S.: Changes in severe thunderstorm environment frequency during the 21 st century caused by anthropogenically enhanced global radiative forcing, P. Natl. Aacad. Sci., 104, 19719-19723, doi:10.1073/pnas.0705494104, 2007.

Trapp, R. J., Diffenbaugh, N. S., and Gluhovsky, A.: Transient response of severe thunderstorm forcing to elevated greenhouse gas concentrations, Geophys. Res. Lett., 36, L01703, doi:10.1029/2008g1036203, 2009.

Volkamer, R., Jimenez, J. L., San Martini, F., Dzepina, K., Zhang, Q., Salcedo, D., Molina, L. T., Worsnop, D. R., and Molina, M. J.: Secondary organic aerosol formation from anthropogenic air pollution: Rapid and higher than expected, Geophys. Res. Lett., 33, L17811, doi:10.1029/2006g1026899, 2006.

White, M. L., Russo, R. S., Zhou, Y., Mao, H., Varner, R. K., Ambrose, J., Veres, P., Wingenter, O. W., Haase, K., Stutz, J., Talbot, R., and Sive, B. C.: Volatile organic compounds in northern New England marine and continental environments during the ICARTT 2004 campaign, J. Geophys. Res., 113, D08S90, doi:10.1029/2007jd009161, 2008.

White, M. L., Russo, R. S., Zhou, Y., Ambrose, J. L., Haase, K., Frinak, E. K., Varner, R. K., Wingenter, O. W., Mao, H., Talbot, R., and Sive, B. C.: Are biogenic emissions a significant source of summertime atmospheric toluene in the rural Northeastern United States?, Atmos. Chem. Phys., 9, 81-92, doi:10.5194/acp9-81-2009, 2009.

WMO: Measurement of Precipitation, in: Guide to Meteorological Insturments and Methods of Observation, 7th Edition, World Meteological Organization (WMO), Geneva, 2008. 